\title{
MICROSSISTEMA RECURSAL: A EXISTÊNCIA DE UM BLOCO NORMATIVO QUE PERMITE DIÁLOGOS ENTRE AS ESPÉCIES RECURSAIS, MEDIANTE INTERCÂMBIO DE TÉCNICAS PROCESSUAIS NOS RECURSOS ${ }^{1}$
}

MICROSYSTEM OF APPEALS: THE EXISTENCE OF A NORMATIVE SET THAT ALLOWS DIALOGUES BETWEEN APPEAL SPECIES THROUGH AN EXCHANGE OF PROCEDURAL TECHNIQUES

Felipe Barreto Marçal Doutorando em Direito Processual pela UFPR, Mestre em Direito Processual pela UERJ. Membro dos Grupos de Pesquisa Transformações nas Estruturas Fundamentais do Processo (UERJ) e Meios Adequados de Solução Heterônoma de Conflitos, Dentro e Fora do Estado (UFPR), ambos integrantes da Rede ProcNet - Rede Internacional de Pesquisa - Justiça Civil e Processo Contemporâneo. Advogado. Rio de Janeiro/RJ.E-mail: fmarcal@schreiber.adv.br

Gabriel Lino Ramos de Macedo Graduando em Direito pela UFRJ e Estagiário na Wald, Antunes, Vita, Longo e Blattner Advogados. Rio de Janeiro/RJ. E-mail: gabrielmacedofnd@gmail.com

RESUMO: O presente artigo pretende apontar a mudança de percepção acerca dos microssistemas normativos, de modo que sua existência também se relaciona com o intercâmbio de normas situadas dentro do mesmo corpo legislativo. Em síntese, não havendo vedação expressa na legislação, deve-se admitir o diálogo normativo, mediante subsidiariedade e supletivismo. A partir dessas premissas, foram identificados os já consagrados microssistemas e alguns "novos", indicados pela doutrina. Além disso, o trabalho objetiva demonstrar a necessidade de se reconhecer a existência de um

\footnotetext{
${ }^{1}$ Artigo recebido em 09/03/2021 e aprovado em 19/07/2021.
} 
microssistema recursal, que permite o intercâmbio de técnicas processuais entre as diferentes espécies de recurso.

PALAVRAS-CHAVE: Microssistemas. Recursos. Tipos. Diálogo. Fontes.

\begin{abstract}
This article aims to point out the change in the perception of the normative microsystems, so that their existence is also related to the exchange of rules located in the same legislative body. In short, without impediment expressly imposed by law, the normative dialogue must be admitted through subsidiarity and suppletivism. From these premises, the already consecrated procedural microsystems and some "new" ones, indicated by the doctrine, were identified. Besides that, the work intends to demonstrate the necessity of recognizing the existence of a microsystem of appeals, which allows the exchange of procedural techniques and rules laid down for certain appeal species.
\end{abstract}

KEYWORDS: Microsystems. Appeals. Species. Dialogue. Sources.

SUMÁRIO: Introdução. 1. Análise dos microssistemas já consagrados no ordenamento brasileiro, a partir da perspectiva tradicional. 1.1. O Microssistema de Defesa do Consumidor. 1.2. O Microssistema dos Juizados Especiais. 1.3. O Microssistema da Arbitragem. 1.4. O Microssistema de Processo Coletivo. 1.5. O Microssistema de Controle Concentrado de Constitucionalidade. 2. A concepção atual e os "novos" microssistemas. 3. A existência de um Microssistema Recursal no Processo Civil Brasileiro. Conclusão. Referências bibliográficas.

\title{
Introdução
}

Até o início do século XIX, reinava na Europa feudal o particularismo jurídico, com os direitos locais regulando a vida da sociedade, que era vinculada a um modelo de estamentos. Era uma normatividade dominantemente consuetudinária que funcionava principalmente de acordo com o território (feudos) e com suas respectivas finalidades (de 
cada um dos senhores feudais), de modo que havia um ordenamento para cada localidade com o fim de satisfazer aos interesses da classe dominante, dos senhores feudais. ${ }^{2}$

Com o advento da Revolução Francesa e de seus ideais influenciados pelo Iluminismo (positivismo jurídico), o antigo modelo social foi substituído por um Estado que descobria a importância de um sistema de codificação comum entre os indivíduos, agora independente do território, mas que levava em consideração os interesses liberais da classe burguesa. ${ }^{3}$ Esta percepção levou à criação do primeiro código moderno de que temos notícia: o Código Napoleônico, de 1804; após esse marco, as codificações espalharam-se pela Europa e pelo mundo, com a aparição de códigos, como o ABGB austríaco, de 1812, e o BGB alemão, de 1900. No Brasil, os primeiros códigos foram o Código Criminal do Império de 1830 e o Código Comercial de 1850; o primeiro Código Civil Brasileiro e o primeiro Código de Processo Civil passaram a vigorar em 1916 e em 1939, respectivamente.

Os chamados microssistemas jurídicos, compreendidos em sua nomenclatura primeva, originaram-se, principalmente no século XX, como consequência da própria ideia de codificação, que pregava a concepção dos códigos como sistemas normativos completos, perpétuos, autossuficientes (hermeticamente fechados em si mesmos), que serviriam para oferecer maior segurança às relações privadas e proporcionar acesso irrestrito à lei.

Todavia, com o passar do tempo, percebeu-se que não há como submeter toda uma realidade a um sistema fechado de normas, como se este fosse capaz de oferecer respostas e soluções a todos os casos concretos possíveis de serem sucedidos em uma sociedade complexa. Passou-se a criar, então, leis extravagantes, com o fim de suprir as lacunas deixadas pelos códigos, de modo que, quando consideradas conjuntamente, formariam sistemas de menor proporção, para serem interpretados em seu conjunto, formando os microssistemas normativos; ${ }^{4}$ uma segunda etapa em sua compreensão (a que chamaremos de concepção "tradicional", por falta de outro termo mais adequado).

Contudo, há autores que, transbordando essa visão tradicional, perceberam, com razão, que os microssistemas podem ser extraídos a partir de blocos normativos presentes dentro de um só corpo normativo (um só código ou uma só lei), que permitiriam diálogos para

\footnotetext{
${ }^{2}$ VIAL, Sophia Martini. O fenômeno da codificação e da recodificação do direito privado. Revista de Direito Privado, v. 64, 2015, p. 13-35, versão eletrônica, p. 2.

${ }^{3}$ VIEIRA, Marcelo de Mello. Considerações sobre microssistemas jurídicos: definição e importância à luz do direito civil-constitucional brasileiro. Juris Plenum, ano XVI, n. 91, 2020, p. 133-134.

${ }^{4}$ Idem, p. 134-135.
} 
suprir aparentes lacunas e para melhorar a interpretação (supletivismo e subsidiariedade). Em outras palavras, a ideia contemporânea une o melhor dos mundos das concepções primeva (suficiência dos códigos, compreendidos como um sistema fechado) e tradicional (diálogos entre fontes normativas diversas).

No ordenamento jurídico brasileiro, é pacífico o entendimento, na doutrina e na jurisprudência, acerca da presença de alguns microssistemas, tais como: o de Defesa do Consumidor, a partir do CDC e de outros dispositivos; o de Juizados Especiais, desenvolvido na Lei 9.099/1995, na Lei 10.259/2001 e na Lei 12.153/2009; o de Arbitragem, diante da Lei 9.037/1996, do Decreto 4.311/2002 e da Lei 13.129/2015; o de Processo Coletivo, por força da Lei 7.347/1985 e do CDC; o de Controle Concentrado de Constitucionalidade, com base na Lei 9.868/1999 e na Lei 9.882/1999; e o de Julgamento de Casos Repetitivos, a partir dos institutos do Incidente de Resolução de Demandas Repetitivas e dos Recursos Repetitivos (presentes também na Lei 13.015/2014).

Nesse sentido, o objeto do presente trabalho é demonstrar a existência de um microssistema recursal inserido no direito processual brasileiro, composto por um conjunto de normas que se interseccionam e se influenciam reciprocamente para proporcionar uma interpretação mais convergente com os princípios processuais, seja por meio da colmatação de lacunas ou do fornecimento de elementos subsidiários de interpretação, o que permite um intercâmbio de técnicas processuais ${ }^{5}$ entre os tipos recursais. ${ }^{6}$

Para essa análise, ao longo do texto, serão percorridos os fundamentos e as características de todos os microssistemas supracitados e a indicação de outros, "novos", o que possibilitará uma posterior comparação destes conjuntos com as normas referentes aos recursos no sistema processual do ordenamento pátrio, com o objetivo de comprovar a existência de um microssistema jurídico, levando em consideração uma pluralidade de dispositivos insertos não só no Código de Processo Civil, mas também em leis extravagantes.

\footnotetext{
${ }^{5}$ Sobre a possibilidade e a necessidade desse "livre trânsito" de técnicas procedimentais: DIDIER JR., Fredie; CABRAL, Antonio do Passo; CUNHA, Leonardo Carneiro. Por uma nova teoria dos procedimentos especiais. Salvador: Ed. JusPodivm, 2018.

${ }^{6}$ Nas palavras do Min. Luiz Fux, o microssistema permite que normas se interpenetrem e se subsidiem (STJ REsp 510.150/MA, Rel. Ministro LUIZ FUX, PRIMEIRA TURMA, julgado em 17/02/2004, DJ 29/03/2004, p. 173.).
} 


\section{Análise dos microssistemas já consagrados no ordenamento brasileiro, a partir da perspectiva tradicional}

Como já dito, na concepção tradicional, os microssistemas constituem verdadeiros "diálogos normativos" operados a partir de aplicação subsidiária, supletiva e analógica ${ }^{7}$ de dispositivos extraídos de fontes normativas diversas. A importância do reconhecimento de microssistemas decorre do fato de que, sem eles, chega-se a resultado diametralmente oposto: o de que normas excepcionais interpretam-se estritamente, impedindo-se a analogia, a subsidiariedade e o supletivismo.

Importante destacar, ainda, que todas as leis processuais extravagantes têm o CPC como lei geral, de modo que ele integrará esses microssistemas processuais, ${ }^{8}$ especialmente

\footnotetext{
${ }^{7}$ Sobre a diferença terminológica: “A aplicação subsidiária ocorre também em situações nas quais não há omissão. Trata-se, como sugere a expressão 'subsidiária', de uma possibilidade de enriquecimento, de leitura de um dispositivo sob outro viés, de extrair-se da norma processual eleitoral, trabalhista ou administrativa um sentido diferente, iluminado pelos princípios fundamentais do processo civil. A aplicação supletiva é que supõe omissão. Aliás, o legislador, deixando de lado a preocupação com a própria expressão, precisão da linguagem, serve-se das duas expressões. Não deve ter suposto que significam a mesma coisa, se não, não teria usado as duas. Mas como empregou também a mais rica, mais abrangente, deve o intérprete entender que é disso que se trata." (ALVIM, Teresa Arruda; CONCEIÇÃO, Maria Lúcia Lins; RIBEIRO, Leonardo Ferres da Silva; MELLO, Rogério Licastro Torres de. Primeiros comentários ao Novo Código de Processo Civil. Artigo por artigo. São Paulo: RT, 2015, p. 75.) Importante destacar que a existência de microssistemas visa justamente a eliminar lacunas e a melhorar a interpretação, por meio das referidas técnicas: analogias, aplicações subsidiárias e supletivas.

${ }^{8}$ Sobre o ponto, confiram-se importantes lições de Barbosa Moreira sobre o procedimento especial do mandado de segurança, escritas à luz do CPC/1973, mas que servem a todo e qualquer procedimento especial ou lei processual extravagante: "É impossível, é absolutamente impossível processar um mandado de segurança utilizando exclusivamente as normas constantes da legislação especial. O que isso significa? Significa aquilo mesmo que, obviamente, significa em qualquer situação parecida com essa, em qualquer situação desse gênero. Significa que as questões não previstas, não reguladas expressamente na legislação específica, devem ser resolvidas à luz da legislação comum. E qual é a legislação comum em matéria processual? Parece-me que é, fundamentalmente, constituída pelo Código de Processo Civil. É claro que poderá haver situações nas quais, embora não encontremos na lei específica uma previsão expressa, categórica, podemos, contudo, inferir da sua sistemática que, num ponto ou noutro, o processamento do mandado de segurança não deve obedecer às regras contidas no Código de Processo Civil. Isto é, os casos em que o Código não se aplica não serão apenas aqueles em que haja disposição expressa e específica na legislação pertinente ao mandado de segurança, mas também aqueles outros que, do ponto de vista sistemático, ofereçam porventura características que nos autorizem a concluir a incompatibilidade entre a norma comum, isto é, a norma contida no Código de Processo Civil, e alguma nota essencial ao instituto do mandado de segurança. Feita essa concessão, continua sendo verdade o essencial, com as ressalvas já formuladas: a disciplina do mandado de segurança, quando não se contenha na legislação especial, é necessariamente complementada pelas normas constantes do direito processual comum, isto é, em outras palavras, pelas normas constantes do Código de Processo Civil. (...) O absurdo ressalta. Na verdade, todos esses equívocos e outros que eu poderia mencionar - não quero alongar-me por demais resultam de uma atitude fundamentalmente errônea, que é a de exilar o mandado de segurança numa espécie de ilha deserta, sem comunicação com o resto do universo processual, quando na verdade ele nada mais é do que uma ação cujo exercício - desculpem mais uma vez - dá lugar a um processo, regulado, naquilo em que não se contrariem as disposições da legislação especial, pelas normas do direito processual comum, que é o
} 
diante do art. 1.046, $\S 2^{\circ}$, do CPC. Feita essa ressalva, merecem análise pormenorizada os principais microssistemas já reconhecidos no Brasil a partir dessa visão tradicional.

\subsection{O Microssistema de Defesa do Consumidor}

A preocupação com a vulnerabilidade do consumidor, retratada pelo art. $2^{\circ}$ do Código de Defesa do Consumidor como "toda pessoa física ou jurídica que adquire ou utiliza produto ou serviço como destinatário final", decorre do reconhecimento de que o avanço tecnológico deflagrado ao logo do tempo fez com que a produção de mercadorias se perfizesse de forma massiva, de acordo com as exigências do capitalismo e do expansionismo atuais. Essa realidade teve como consequência a constituição de uma cultura do consumo que transformou as relações sociais, econômicas e jurídicas, nestas quais o consumidor é posto em uma posição de maior fragilidade em relação ao fornecedor, conceituado pelo art. $3^{\circ}$ do CDC como "toda pessoa física ou jurídica, pública ou privada, nacional ou estrangeira, bem como os entes despersonalizados, que desenvolvem atividade de produção, montagem, criação, construção, transformação, importação, exportação, distribuição ou comercialização de produtos ou prestação de serviços". 9

A Lei $n^{\circ}$ 8.078/90 deu origem ao Código de Defesa do Consumidor no Brasil. O CDC foi responsável por formar o núcleo do, aqui chamado, Microssistema de Defesa do

contido no Código de Processo Civil." (MOREIRA, José Carlos Barbosa. Mandado de segurança - uma apresentação, in: Temas de direito processual - sexta série. São Paulo: Saraiva, 1997, p. 205-207.) "À semelhança do que acontece com as figuras congêneres, o mandado de segurança está contido no âmbito normativo do processo civil e submete-se aos respectivos princípios e normas, sem prejuízo da regulamentação especial constante das leis que a ele especificamente dizem respeito. Em outras palavras: sempre que não colidam com disposição particular da legislação extravagante, nem se revelem incompatíveis com a sistemática nesta consagrada, incidem aqui as regras gerais inscritas no Código de Processo Civil, onde se contêm os mencionados princípios e normas. Funciona o Código, por assim dizer, como reservatório a que só não se recorrerá quando motivo imperioso, tirado da legislação extravagante, imponha atitude diversa. Nem se concebe que fosse de outra forma. A legislação específica, muito compreensivelmente, é omissa quanto a grande número de questões da maior relevância (...). Mas é evidente que tais questões não podem ficar sem solução no processo do mandado de segurança. Aplica-se-lhes, então, a disciplina encontrada no diploma processual comum: de que outra se poderia cogitar? Aliás, o art. 273 do Código é categórico em estatuir: 'O procedimento especial e o procedimento sumaríssimo regem-se pelas disposições que lhes são próprias, aplicando-se-lhes, subsidiariamente, as disposições gerais do procedimento ordinário'. Não se estabelece diferença, aí, entre procedimentos especiais regulados no Código mesmo e procedimentos especiais regulados noutras leis. Todos, sem distinção, sujeitam-se a igual regime." - grifos do autor (MOREIRA, José Carlos Barbosa. Recorribilidade das decisóes interlocutórias no processo do mandado de segurança, in: Temas de direito processual - sexta série. São Paulo: Saraiva, 1997, p. 212-213.)

${ }^{9}$ KLAUSNER, Eduardo Antônio. A globalização e a proteção do consumidor brasileiro. Revista de Direito do Consumidor, v. 97, 2015, p. 67-84, versão eletrônica, p. 3-4. 
Consumidor, principal legislação expoente da ideia de microssistemas no país. ${ }^{10}$ Além de possuir suas bases na Constituição, o Microssistema de Defesa do Consumidor, com sua multidisciplinariedade, envolve normas de Direito Civil, Penal, Processual e Administrativo. ${ }^{11}$ Para comprovar isto, basta citar, do CDC: o capítulo VII do título I, que cuida das sanções administrativas; o título II, que cuida das infrações penais; e o título III, responsável por trazer normas processuais importantes que possibilitam até mesmo, como já visto, que os consumidores beneficiem-se de ações coletivas. ${ }^{12}$

Como explica Squeff, a Lei nº 8.078/90 é específica, o que faz com que não incida em toda a realidade jurídico-social, mas que tenha preferência de aplicação em circunstâncias que são englobadas pela parcela objeto do Microssistema de Defesa do Consumidor. O que deve acontecer, por certo, é uma complementação recíproca, uma coordenação entre as normas, a fim de que o consumidor (vulnerável) seja protegido de acordo com a CRFB/88, ${ }^{13}$ compreensão extraível do art. $7^{\circ}$ do CDC (“Os direitos previstos neste código não excluem outros decorrentes de tratados ou convenções internacionais de que o Brasil seja signatário, ${ }^{14}$ da legislação interna ordinária, de regulamentos expedidos pelas autoridades administrativas competentes, bem como dos que derivem dos princípios gerais do direito, analogia, costumes e equidade.").

Além disso, a tutela ao consumidor também possui relação com outros microssistemas, que serão indicados abaixo, como, por exemplo, o de tutela coletiva e de julgamento de casos repetitivos.

\subsection{O Microssistema dos Juizados Especiais}

\footnotetext{
${ }^{10}$ VIAL, Sophia Martini. O fenômeno da codificação e da recodificação do direito privado. Revista de Direito Privado, v. 64, 2015, p. 13-35, versão eletrônica, p. 6.

${ }^{11}$ AZEVEDO, Fernando Costa de. Uma introdução ao direito brasileiro do consumidor. Revista de Direito do Consumidor, v. 69, 2009, p. 32-86, versão eletrônica, p. 5.

12 TEIXEIRA, Sálvio de Figueiredo. A proteção ao consumidor no sistema jurídico brasileiro. Revista de Direito do Consumidor, v. 60, 2006, p. 7-36, versão eletrônica, p. 4-5.

${ }^{13}$ SQUEFF, Tatiana de Almeida F. R. Cardoso. Bases constitucionais da defesa dos consumidores no Brasil: um resgate acerca da criação da legislação consumerista em prol da confirmação de sua posição privilegiada no ordenamento jurídico pátrio. Revista de Direito do Consumidor, v. 116, 2018, p. 129-149, versão eletrônica, p. 6-8.

14 Como exemplo: a Convenção de Varsóvia, promulgada pelo Decreto $n^{\circ}$ 20.704/1931; bem como a Convenção de Montreal, promulgada pelo Decreto nº 5.910/2006.
} 
O Microssistema dos Juizados Especiais surgiu, paulatinamente, como solução aos problemas de acesso à justiça para direitos de pouca expressão econômica ou considerados de pouca complexidade pelo legislador ${ }^{15-16}$. Essa situação problemática, que existia em razão da complexidade do modelo de processo tradicional, começou a ser reduzida com a entrada em vigor da Lei 7.244/84, que dispunha sobre a criação dos Juizados Especiais de Pequenas Causas nas justiças dos Estados, do Distrito Federal e dos Territórios. A referida Lei foi revogada pela Lei 9.099/95, que regulou a criação dos Juizados Especiais Cíveis e Criminais inseridos no âmbito da Justiça Comum, de acordo com as disposições da CRFB/88, em seus artigos $24, \mathrm{X}$, e $98, \mathrm{I}$, e $\S 1^{\circ}$. Este novo regulamento criou um procedimento próprio a ser colocado em prática pelos juizados da Justiça Ordinária, com uma principiologia e uma finalidade próprias, que lhe conferiam certa autonomia sistemática em relação ao CPC/1973. ${ }^{17}$

Após a Lei 9.099/95, sobreveio a Lei 10.259/2001, que dispõe sobre a instituição dos Juizados Especiais Cíveis e Criminais no âmbito, desta vez, da Justiça Federal, a fim de atender ao art. 24, X, e o art. 98, $§ 1^{\circ}$, da CRFB/88. A criação dos Juizados Especiais Federais corroborou ainda mais a ampliação do acesso à justiça e ao Judiciário, possibilitando, v.g., que demandas que versam sobre direito previdenciário pudessem ser apreciadas de forma mais fácil.

Cabe esclarecer um ponto: apesar de a Lei 10.259/2001 dispor, de forma expressa em seu art. $1^{\circ}$, que as normas da Lei 9.099/95 lhes são aplicadas subsidiariamente, a recíproca também é verdadeira. ${ }^{18}$

\footnotetext{
${ }^{15}$ MENDES, Aluisio Gonçalves de Castro; NETO, Odilon Romano. Análise da relação entre o novo incidente de resolução de demandas repetitivas e o microssistema dos juizados especiais. Revista de Processo, v. 245, 2015, p. 275-309, versão eletrônica, p. 3-6. PEREIRA, Vívian Lopes. A nova sistemática executiva do código de processo civil e os seus reflexos nos juizados especiais estaduais cíveis. Revista de Processo, v. 198, 2011, p. 297-317, versão eletrônica, p. 2.

${ }^{16} \mathrm{O}$ "acesso à justiça", como o alcance de uma ordem jurídica justa, diferencia-se do "acesso ao Judiciário", que evita a litigiosidade contida. CÂMARA, Alexandre Freitas. Juizados especiais cíveis estaduais, federais e da fazenda pública: uma abordagem crítica. $7^{\mathrm{a}}$ ed., Rio de Janeiro: Lumen Juris, 2012, p. 5.

${ }^{17}$ PEREIRA, Vívian Lopes. Op. Cit., p. 2-4.

18 “(...) Exemplifico: a Lei 9.099/1995 não permite a interposição de recurso contra as decisões interlocutórias. Isso faz com que haja um emprego exagerado do mandado de segurança contra ato judicial, transformando-o em sucedâneo recursal. Ocorre que a Lei dos Juizados Federais permite a interposição de recurso contra a decisão interlocutória que defere ou indefere medidas de urgência. Isso torna possível, a meu ver, a interposição de tal recurso também no processo dos Juizados Especiais Estaduais, viabilizando-se o reexame de tais decisões por via recursal." (CÂMARA, Alexandre Freitas. Juizados especiais cíveis estaduais, federais e da fazenda pública: uma abordagem crítica. $7^{\text {a }}$ ed., Rio de Janeiro: Lumen Juris, 2012, p. 4.)
} 
As duas Leis complementam-se e comunicam-se entre si, constituindo-se, deste modo, um microssistema do qual a Lei $12.153 / 2009$ posteriormente também passou a integrar. Esta última surgiu com o fim de dispor sobre os Juizados Especiais da Fazenda Pública, que fazem parte da estrutura dos Juizados Especiais Estaduais. ${ }^{19}$ Esta regulamentação é importantíssima para a demonstração ainda mais clara da intercomunicação existente, visto que dispõe expressamente, em seu art. 27, a aplicação subsidiária do CPC, da Lei dos Juizados Especiais Estaduais e da Lei dos Juizados Especiais Federais. ${ }^{20}$

A vigência, então, de um microssistema formado não só pelas Leis 9.099/95, 10.259/2001 e 12.153/2009, mas também por dispositivos do Código de Processo Civil de 2015 fica evidente. Este conjunto normativo contém princípios próprios, ligados à oralidade, simplicidade, informalidade, economia processual e celeridade, mencionados pelo art. $2^{\circ}$ da Lei 9.099/05, ${ }^{21}$ mas não pode deixar de conciliá-los com as regras e princípios do CPC, a fim de alcançar uma melhor e mais efetiva prestação jurisdicional às causas de pequena expressão econômica e de pouca complexidade.

\subsection{O Microssistema da Arbitragem}

Como se sabe, o processo jurisdicional não é o único meio pelo qual as pessoas podem resolver os litígios que surgem entre si (art. $3^{\circ}$ do CPC). Muitas das vezes o sistema judiciário nem mesmo oferece o procedimento mais adequado à resolução de determinados casos. Posteriormente à Constituição de 1988, passaram a vigorar a Lei de Arbitragem no 9.307/96 e o Decreto 4.311/2002, regulamentos que compõem o núcleo do Microssistema de Arbitragem,${ }^{22}$ que versa sobre um meio de resolução extrajudicial de conflitos que abarcam direitos patrimoniais e disponíveis.

É indispensável esclarecer que os dois atos normativos citados, a Lei no 9.307/96 e o Decreto 4.311/2002, este último que promulga a Convenção sobre o Reconhecimento e a

\footnotetext{
${ }^{19}$ MENDES, Aluisio Gonçalves de Castro; NETO, Odilon Romano. Análise da relação entre o novo incidente de resolução de demandas repetitivas e o microssistema dos juizados especiais. Revista de Processo, v. 245, 2015, p. 275-309, versão eletrônica, p. 5.

${ }^{20}$ CÂMARA, Alexandre Freitas. Op. Cit., p. 4-5.

${ }^{21}$ PEREIRA, Vívian Lopes. A nova sistemática executiva do código de processo civil e os seus reflexos nos juizados especiais estaduais cíveis. Revista de Processo, v. 198, 2011, p. 297-317, versão eletrônica, p. 3-4.

${ }^{22}$ DIDIER JR., Fredie. Curso de direito processual civil: introdução ao direito processual civil, parte geral e processo do conhecimento, v. 1. 22 a ed. rev., atual. e ampl., Salvador: Juspodivm, 2020, p. 71.
} 
Execução de Sentenças Arbitrais Estrangeiras, relacionam-se com outros diplomas, principalmente com o CPC, como já dito. ${ }^{23-24}$ Por outro lado, o CPC também promove normas especialmente direcionadas a eles, como o fez reconhecendo a arbitragem como espécie de jurisdição, em seu art. $3^{\circ},{ }^{25}$ e estabelecendo que o processo jurisdicional deve ser encerrado, caso o juízo arbitral reconheça sua competência, no art. 485, VII, dentre outros. ${ }^{26}$

Outro diploma normativo que veio fazer parte do Microssistema da Arbitragem é a Lei 13.129/2015, que modificou e ampliou o âmbito de aplicação da Arbitragem, fazendo com que, v.g., a carta arbitral passasse a ser prevista expressamente na Lei 9.307/96. Inegável, pois, a vigência de um microssistema arbitral composto por normas que se complementam e se influenciam, devendo estas serem interpretadas de forma conjunta.

\subsection{O Microssistema de Tutela Coletiva}

Anteriormente ao fenômeno da descodificação, o processo era baseado em disputas individuais que envolvem alguns poucos sujeitos e o juiz, numa relação de triangularidade. Como explicam Didier Jr. e da Cunha, "a legislação processual disciplina, tradicionalmente, o processo individual: as normas que disciplinam o processo civil foram estruturadas de modo a considerar única cada demanda, veiculando um litígio específico entre duas pessoas". ${ }^{27} \mathrm{O}$ desenvolvimento social, já citado neste trabalho, também foi responsável por gerar a percepção de que o procedimento judicial outrora vigente, cujo aspecto era

\footnotetext{
${ }^{23}$ Nesse sentido, a própria Lei de Arbitragem cita o CPC em diversas passagens, como em seu art. 14, que dispõe: "Estão impedidos de funcionar como árbitros as pessoas que tenham, com as partes ou com o litígio que lhes for submetido, algumas das relações que caracterizam os casos de impedimento ou suspeição de juízes, aplicando-se-lhes, no que couber, os mesmos deveres e responsabilidades, conforme previsto no Código de Processo Civil."

${ }^{24} \mathrm{Na}$ mesma toada: FONSECA, Rodrigo Garcia da. A arbitragem e a reforma processual da execução. Revista de Arbitragem e Mediação, v. 14, 2007, p. 30-47, versão eletrônica, p. 1-2.

${ }^{25}$ DIDIER JR., Fredie. Curso de direito processual civil: introdução ao direito processual civil, parte geral e processo do conhecimento, v. 1. $22^{\mathrm{a}}$ ed. rev., atual. e ampl., Salvador: Juspodivm, 2020, p. 73.

${ }^{26}$ Além deste dispositivo inserido no Código Processual, há vários outros: por exemplo, o art. 189, IV, que versa sobre o trâmite em segredo de justiça dos processos arbitrais; o art. $260, \S 3^{\circ}$, que prevê a carta arbitral; o art. 337, X, que incumbe ao réu a alegação da convenção de arbitragem antes da discussão do mérito em processo judicial; o art. $1.012, \S 1^{\circ}$, IV, que limita o efeito suspensivo da apelação quando julgado procedente o pedido de instituição de arbitragem; o art. 1.015, III, que torna agravável a decisão que rejeita a alegação de convenção de arbitragem; e o art. 1.061, que modificou a redação do $\$ 3^{\circ}$ do artigo 33 da Lei de Arbitragem.

${ }^{27}$ DIDIER JR., Fredie; CUNHA, Leonardo Carneiro da. Curso de direito processual civil: meios de impugnação às decisões judiciais e processo nos tribunais, v. 3. $17^{\mathrm{a}}$ ed. rev., atual. e ampl., Salvador: Juspodivm, 2020, p. 722.
} 
Revista Eletrônica de Direito Processual - REDP.

Rio de Janeiro. Ano 16. Volume 23. Número 1. Janeiro a Abril de 2022

Periódico Quadrimestral da Pós-Graduação Stricto Sensu em Direito Processual da UERJ

Patrono: José Carlos Barbosa Moreira (in mem.). ISSN 1982-7636. pp. 458-481

www.redp.uerj.br

individualista, não era eficiente o bastante para colocar em prática a jurisdição em sociedades complexas, com multiplicidade de demandas similares em razão de direitos agora considerados como difusos, coletivos e individuais homogêneos. ${ }^{28}$

No Brasil, um Microssistema de Processo Coletivo ou de Tutela Coletiva é reconhecido pela doutrina e pela jurisprudência, ${ }^{29}$ composto essencialmente por duas leis: a Lei de Ação Civil Pública (Lei n ${ }^{\circ}$ 7.347/85) e o Código de Defesa do Consumidor (Lei no 8.078/90). ${ }^{30} \mathrm{~A}$ importância deste último é de tal tamanho e seus dispositivos influenciam de tal maneira o conjunto normativo, que alguns chegam a afirmar que o seu Título III constitui um verdadeiro "Código Brasileiro de Processos Coletivos". ${ }^{31}$ Não obstante, fato é que os dois diplomas relacionam-se mutuamente: isto torna-se claro pela leitura do art. 90 do CDC e do art. 21 da LACP, ${ }^{32}$ operando-se um "diálogo das fontes". 33

É inegável reconhecer que o Código de Defesa do Consumidor atuou como agente de unificação e harmonia entre o CPC e a LACP, quando em seu art. 90 determinou a aplicação conjunta destes dois regulamentos. ${ }^{34}$ Sob essa perspectiva, é admissível alegar que o Código de Processo Civil passa a interagir de forma direta com as normas que integram o

\footnotetext{
${ }^{28}$ MOREIRA, José Carlos Barbosa. A ação popular do direito brasileiro como instrumento de tutela dos chamados 'interesses difusos', in: Temas de direito processual - primeira série. São Paulo: Saraiva, 1988, p. 110-123. Idem. A legitimação para a defesa dos "interesses difusos" no direito brasileiro, in: Temas de direito processual - terceira série. São Paulo: Saraiva, 1984, p. 183-192. Idem. A proteção jurídica dos interesses coletivos, in: Temas de direito processual - terceira série. São Paulo: Saraiva, 1984, p. 173-181. Idem. Ações coletivas na Constituição Federal de 1988. Revista de Processo, n. 61, 1991, p. 187. CABRAL, Antonio do Passo. A escolha da causa-piloto nos incidentes de resolução de processos repetitivos. Revista de Processo, $n$. 231, 2014, p. 201.

29 “Como salientado, tratando-se de ação civil pública, já decidiu esta Corte que, à míngua de disposição legal específica, há de valer o julgador de dispositivo inserido no microssistema das tutelas coletivas [...]." (STJ, AgInt no REsp 1.807.990/SP, Rel. Ministra MARIA ISABEL GALLOTTI, QUARTA TURMA, julgado em 20/04/2020, DJe 24/04/2020)

${ }^{30}$ DIDIER JR., Fredie. Curso de direito processual civil: introdução ao direito processual civil, parte geral e processo do conhecimento, v. 1. $22^{\mathrm{a}}$ ed. rev., atual. e ampl., Salvador: Juspodivm, 2020, p. 71. ROQUE, Andre Vasconcelos. As ações coletivas após o Novo Código de Processo Civil: para onde vamos? In: DIDIER JR., Fredie; ZANETI JR., Hermes (coords.). Coleção repercussões do Novo CPC: processo coletivo, v.8. Salvador: Juspodivm, 2016, p. 172.

${ }^{31}$ DIDIER JR., Fredie; ZANETI JR., Hermes. Curso de direito processual civil: processo coletivo, v. 4. $10^{\mathrm{a}}$ ed., Salvador: Juspodivm, 2016, p. 52.

${ }^{32}$ Art. 90, CDC: "Aplicam-se às ações previstas neste título as normas do Código de Processo Civil e da Lei $\mathrm{n}^{\circ}$ 7.347, de 24 de julho de 1985, inclusive no que respeita ao inquérito civil, naquilo que não contrariar suas disposições."; Art. 21, LACP: "Aplicam-se à defesa dos direitos e interesses difusos, coletivos e individuais, no que for cabível, os dispositivos do Título III da lei que instituiu o Código de Defesa do Consumidor."

${ }^{33}$ BASTOS, Fabrício Rocha. Do microssistema da tutela coletiva e sua interação com o CPC/15. Revista do Ministério Público do Rio de Janeiro, n. 68, 2018, p. 59-60.

${ }^{34}$ DIDIER JR., Fredie; ZANETI JR., Hermes. Op. Cit., p. 51-52.
} 
Revista Eletrônica de Direito Processual - REDP.

Rio de Janeiro. Ano 16. Volume 23. Número 1. Janeiro a Abril de 2022

Periódico Quadrimestral da Pós-Graduação Stricto Sensu em Direito Processual da UERJ

Patrono: José Carlos Barbosa Moreira (in mem.). ISSN 1982-7636. pp. 458-481

www.redp.uerj.br

Microssistema de Processo Coletivo, oferecendo dispositivos que passam a fazer parte desde conjunto normativo. ${ }^{35}$

O Microssistema de Processo Coletivo, contudo, não se restringe à LACP, ao CDC e ao CPC. Além destes, outros também versam sobre tutela coletiva, como, por exemplo: a Lei de Ação Popular (Lei n $\left.{ }^{\circ} 4.717 / 65\right) ;{ }^{36}$ os art. $3^{\circ}$ a $7^{\circ}$ do Estatuto da Pessoa com Deficiência (Lei n ${ }^{\circ} 7.853 / 89$ ); $\mathrm{o}$ art. $3^{\circ}$ da Lei 7.913/89; os art. 210 a 213, 215, 217 a 229 e 222 a 224 do Estatuto da Criança e do Adolescente (Lei n ${ }^{\circ}$ 8.069/90); o art. $2^{\circ}$ da Lei 9.494/97; os art. 80 a 83, 85 e 91 a 93 do Estatuto do Idoso (Lei n ${ }^{\circ} 10.741 / 2003$ ); bem como os art. 21 e 22 da Lei do Mandado de Segurança (Lei n $\left.{ }^{\circ} 12.016 / 2009\right) .{ }^{37}$

\subsection{O Microssistema de Controle Concentrado de Constitucionalidade}

Esse microssistema é composto por normas que regulam os diversos tipos de procedimentos de controle de constitucionalidade (ADI, ADC, ADO, ADPF - Leis $\mathrm{n}^{\text {os }}$ 9.868/99, 12.063/2009 e 9.882/99).Sendo assim, é possível escolher o modelo de controle pelo qual protegerá seus preceitos constitucionais, visando a impedir o retrocesso social sobre questões de direitos fundamentais que impossibilitam a concentração do poder e

\footnotetext{
${ }^{35}$ Nesta toada, o CPC/15 faz referência expressa às ações coletivas em seu art. 139, inc. X, quando determina o envio de ofício aos legitimados pela LACP e pelo CDC a promoverem ações coletivas quando o juiz se deparar com diversas demandas individuais repetitivas; bem como em seu art. 985, inc. I e II, quando determina a aplicação de tese jurídica resultante de julgamento de Incidente de Resolução de Demandas Repetitivas "a todos os processos individuais ou coletivos que versem sobre idêntica questão de direito e que tramitem na área de jurisdição do respectivo tribunal" e "aos casos futuros que versem idêntica questão de direito e que venham a tramitar no território de competência do tribunal". Ainda na mesma perspectiva devem ser interpretados, v.g., o art. 319, inc. VII e o art. $334, \S 4^{\circ}$, ambos do CPC, que possibilitam a realização de audiência de conciliação ou de mediação nos processos coletivos, visto que não há nenhuma contradição com o restante do Microssistema; esta interpretação é feita conjuntamente ao art. $5^{\circ}$, $6^{\circ}$ da LACP, que tem notório caráter de autocomposição. Não esqueça-se, entretanto, que as normas fundamentais e grais do processo fornecidas pelo CPC, como as situadas em seu Livro I, por exemplo, das quais decorrem alguns princípios como o da primazia da resolução de mérito e o da adaptabilidade, também precisam ser levadas em conta nas ações coletivas e na aplicação de seus regulamentos.

${ }^{36}$ Cujo art. $6^{\circ}, \S 3^{\circ}$, é a base normativa que permitiu a construção da ideia de despolarização do processo, coletivo ou individual: CABRAL, Antonio do Passo. Despolarização do processo e "zonas de interesse": sobre a migração entre polos da demanda, in: DIDIER JR., Fredie et al. (Coord.). Tutela jurisdicional coletiva. $2^{\mathrm{a}}$ série. Salvador: Juspodivm, 2012, p. 62. TEMER, Sofia Orberg. Incidente de resolução de demandas repetitivas. Salvador: Juspodivm, 2016.

${ }^{37}$ ROQUE, Andre Vasconcelos. As ações coletivas após o Novo Código de Processo Civil: para onde vamos? In: DIDIER JR., Fredie; ZANETI JR., Hermes (coords.). Coleção repercussões do Novo CPC: processo coletivo, v.8. Salvador: Juspodivm, 2016, p. 173.
} 
efetivam a dignidade da pessoa humana, ${ }^{38}$ já tendo havido reconhecimento pelo STF sobre o intercâmbio de técnicas entre os referidos procedimentos. ${ }^{39}$

\section{A concepção atual e os "novos" microssistemas.}

Trabalhar com a ideia tradicional de microssistemas (dispositivos extraídos a partir de diferentes fontes normativas) acaba por ser um verdadeiro "tiro no pé", pois restringe $o$ mecanismo que tem como finalidade ampliar as fontes de interpretação. Não há qualquer justificativa, hermenêutica ou legislativa; pelo contrário, os arts. $4^{\circ}$ e $5^{\circ}$ da $\operatorname{LINDB}^{40}$ privilegiam o diálogo de fontes e o uso dos "blocos normativos".

Hoje, a existência de um microssistema não fica limitada a essa concepção, mas também engloba os conjuntos de normas intercomunicantes que disciplinam um instituto específico ou um agrupamento de institutos vinculados entre si. Dessa forma, a atual (e alargada) concepção de microssistema permite intercâmbio de normas situadas dentro do mesmo corpo legislativo, de modo que os microssistemas não precisam ter seus núcleos situados fora dos códigos, podendo até mesmo estarem totalmente inseridos neles. ${ }^{41}$ Nesse sentido, a fim de que seja formado um microssistema, de acordo com a ideia do próprio substantivo "sistema", basta que exista uma combinação de normas coordenadas para um mesmo resultado sobre um determinado instituto ou grupo de institutos vinculados, ${ }^{42}$ passando a constituir um verdadeiro bloco normativo. Em síntese, não havendo vedação expressa na legislação, deve-se admitir o diálogo normativo, mediante subsidiariedade e supletivismo.

\footnotetext{
${ }^{38}$ RAMOS, Paulo Roberto Barbosa. A filosofia do controle concentrado de constitucionalidade das leis na ordem jurídica brasileira pós-88. Revista de Direito Constitucional e Internacional, v. 37, 2001, p. 175-184, versão eletrônica, p. 2-3.

${ }^{39}$ Neste sentido: STF - ADPF 381 AgR/DF, Rel. Ministro GILMAR MENDES, julgamento em 15/12/2016, DJe 01/02/2017; STF - ADPF 717 MC/DF, Rel. Ministro LUIZ FUX, julgamento em 03/08/2020, DJe $05 / 08 / 2020$.

40 “Art. $4^{\circ}$ Quando a lei for omissa, o juiz decidirá o caso de acordo com a analogia, os costumes e os princípios gerais de direito.

Art. $5^{\circ} \mathrm{Na}$ aplicação da lei, o juiz atenderá aos fins sociais a que ela se dirige e às exigências do bem comum." ${ }^{41}$ DIDIER JR., Fredie. Curso de direito processual civil: introdução ao direito processual civil, parte geral e processo do conhecimento, v. 1. $22^{\mathrm{a}}$ ed. rev., atual. e ampl., Salvador: Juspodivm, 2020, p. 76.

${ }^{42}$ AZEVEDO, Marcelo Tadeu Freitas de. A natureza jurídica do incidente de resolução de demandas repetitivas. Revista de Processo, v. 278, 2018, p. 337-361, versão eletrônica, p. 3.
} 
A identificação dos "novos" microssistemas, portanto, trabalha com um raciocínio teleológico dos institutos analisados (primeiro momento), para que se busquem outros dispositivos, em institutos semelhantes, permitindo-se um intercâmbio de técnicas procedimentais (segundo momento), ${ }^{43}$ com o objetivo de maximizar as finalidades pretendidas. Exige-se, pelo menos: $i$ ) a intenção de se regular determinada parcela da realidade, instituto específico ou grupo de institutos associados; ii) a existência de um núcleo normativo; e iii) caráter integrativo, com normas que se intercomunicam, de forma subsidiária e supletiva, dentre institutos semelhantes com a mesma finalidade.

Importante destacar uma outra vantagem hermenêutica dessa nova concepção, qual seja, a dispensa de que o legislador tenha antecipado essas interações normativas, o que permite ao intérprete atuar de forma mais "completa", dispondo de mais instrumentos processuais. ${ }^{44}$ Além disso, nada impede que um microssistema formado internamente (numa mesma lei) seja complementado por normas de leis extravagantes. ${ }^{45}$

Diante dessa nova forma de pensar os microssistemas, identificam-se, além dos microssistemas já amplamente consagrados, outros surgidos dentro do CPC, tais como: de julgamento de casos repetitivos (expressamente previsto pelo art. 928 do CPC) ${ }^{46}$ de

\footnotetext{
${ }^{43}$ DIDIER JR., Fredie; CABRAL, Antonio do Passo; CUNHA, Leonardo Carneiro. Por uma nova teoria dos procedimentos especiais. Salvador: Ed. JusPodivm, 2018.

${ }^{44}$ Assim, por exemplo, se o princípio da primazia de resolução do mérito (art. $4^{\circ}$ do CPC) estabelece que se deve buscar a análise do mérito, sempre que possível, é possível combinar dispositivos esparsos do CPC para ampliar essa busca: o art. 76 trata de vícios de capacidade, mas pode ser conjugado com as normas sobre nulidades, de modo que o processo (ou o recurso), em determinados casos, possa ser julgado se a irregularidade tiver sido verificada posteriormente à prática do ato. Isso demonstra a existência de um conjunto de normas que devem ser interpretadas conjuntamente, mesmo em situações para as quais elas não haviam sido inicialmente propostas, desde que se busque a concretização de um princípio (finalidade pretendida pelo legislador).

${ }^{45}$ Apesar do art. 928 do CPC não citar os Recursos de Revista Repetitivos, referentes ao processo do trabalho e regulados pela Lei $\mathrm{n}^{\circ}$ 13.015/2014, estes também fazem parte do Microssistema, de acordo com o Enunciado 346 do FPPC: "A Lei $n^{\circ} 13.015$, de 21 de julho de 2014, compõe o microssistema de solução de casos repetitivos."

${ }^{46}$ Enunciado 345 do Fórum Permanente de Processualistas Civis (FPPC): "O incidente de resolução de demandas repetitivas e o julgamento dos recursos extraordinários e especiais repetitivos formam um microssistema de solução de casos repetitivos, cujas normas de regência se complementam reciprocamente e devem ser interpretadas conjuntamente." Apesar de o art. 928 do CPC incluir somente o Incidente de resolução de demandas repetitivas e os recursos especial e extraordinário repetitivos, há outros institutos que se destinam à litigiosidade repetitiva: CUNHA, Leonardo Carneiro da. O regime processual das causas repetitivas. Revista de Processo, n. 179, 2010. DIDIER JR., Fredie; CUNHA, Leonardo Carneiro da. Curso de direito processual civil: o processo civil nos tribunais, recursos, ações de competência originária de tribunal e querela nullitatis, incidentes de competência originária de tribunal. 13ª ed. reform. - Salvador: Juspodivm, 2016, p. 588-589.
} 
Revista Eletrônica de Direito Processual - REDP.

Rio de Janeiro. Ano 16. Volume 23. Número 1. Janeiro a Abril de 2022

Periódico Quadrimestral da Pós-Graduação Stricto Sensu em Direito Processual da UERJ

Patrono: José Carlos Barbosa Moreira (in mem.). ISSN 1982-7636. pp. 458-481

www.redp.uerj.br

formação e de aplicação de padrões decisórios (extraído a partir do art. 927 do CPC) ${ }^{47}$ de intervenção de terceiros; ${ }^{48}$ e de tutela de terceiros na execução. ${ }^{49}$

Além desses, parcela da doutrina tem sustentado a existência de um "sistema" de formação e aplicação de precedentes no âmbito administrativo, principalmente com a entrada em vigor da Lei $\mathrm{n}^{\mathbf{0}} 13.655 / 2018$, que alterou a Lei de Introdução às Normas do Direito Brasileiro, e da Lei da Liberdade Econômica n ${ }^{\circ} 13.874 / 2019,{ }^{50}$ a fim de conferir maior eficácia aos princípios da segurança jurídica e da eficiência, ${ }^{51}$ previstos pelo art. $2^{\circ}$, caput, da Lei do Processo Administrativo no Âmbito Federal no 9.784/99. ${ }^{52-53}$

\section{A existência de um Microssistema Recursal no Processo Civil Brasileiro}

Até aqui, analisaram-se os núcleos normativos, os fundamentos e as características de alguns dos principais microssistemas processuais consagrados pelo ordenamento jurídico

\footnotetext{
${ }^{47}$ CÂMARA, Alexandre Freitas. Levando os padrões decisórios a sério. São Paulo: Atlas, 2018, p. $254-255$. Enunciados $n^{\text {os }} 459$ e 460 do FPPC. Cabe destacar as possibilidades dadas pelos artigos 332, II e III; 496, §4, II e III; 311, II; 932, IV, $b$ e $c, \mathrm{~V}, b$ e $c$; 955, parágrafo único, II; 983; 984; 988, IV, e $\$ 5^{\circ}$, II; 1.022, parágrafo único, I; 1.038, I, todos do CPC/15 e pelo art. 896-C, $\S 8^{\circ}$, da CLT.

${ }^{48}$ Por todos: TEMER, Sofia Orberg. Participação no Processo Civil: repensando litisconsórcio, intervenção de terceiros e outras formas de atuação. Salvador: Juspodivm, 2020.

${ }^{49}$ Sobre o tema: DIDIER JR., Fredie; OLIVEIRA, Rafael Alexandria de. Intimação de terceiros na execução judicial: uma análise do bloco normativo formado pelos arts. 799, 804 e 889 do Código de Processo Civil brasileiro. Revista Brasileira de Direito Processual, ano 28, n. 110, 2020, p. 155-180.

50 DIDIER JR., Fredie. Intervenção de amicus curiae em processo apto à formação de precedente administrativo obrigatório. Civil Procedure Review, v. 11, n. 2, 2020, p. 211-215.

${ }^{51}$ Além destes princípios, a formação e aplicação de precedentes na Administração Pública baseia-se, também, na concretização do princípio da igualdade derivado da CRFB/88, em razão de não permitir que determinada questão seja decidida de forma diferente em casos semelhantes: BARROS, Marco Antonio Loschiavo Leme de. Processo, precedentes e as novas formas de justificação da Administração Pública Brasileira. Revista Digital de Direito Administrativo, v. 3, n. 1, 2016, p. 138.

${ }^{52}$ Da Lei 9.784/99 cabe destacar o art. $2^{\circ}$, p.ú., inc. XIII, que deve ser interpretado em conjunto com o art. 50, inc. VII, da mesma Lei, corroborando a existência de precedentes administrativos. O Caput do art. 30 da LINDB, da mesma forma, ao supor a existência dos precedentes administrativos, impor a consolidação de seus enunciados e conferir força vinculante aos mesmos, concretiza o art. $2^{\circ}$, p.ú., inc. XII, da Lei 9.784/99. O inciso IV do art. $3^{\circ}$ da Lei 13.874/2019 também é responsável por contribuir com o Microssistema ao determinar que os atos de liberação da Administração Pública são vinculados à interpretação adotada em decisões administrativas análogas anteriores. Além disso, A Lei da Liberdade Econômica, em seu art. 13, alterando o art. 19 da Lei $\mathrm{n}^{\circ}$ 10.522/2002, definiu que a Procuradoria-Geral da Fazenda Nacional fica dispensada de contestar, oferecer contrarrazões e interpor recursos, ao mesmo tempo que fica autorizada a desistir de recursos já interpostos, desde que inexista outro fundamento relevante, nas hipóteses inseridas nos incisos II, IV, V VI e VII. Ainda na mesma toada e acrescentando o art. 18-A à Lei $n^{\circ} 10.522 / 2002$, a Lei $n^{\circ} 13.874 / 2019$ foi a responsável por alçar o regime de precedentes obrigatórios na Administração Pública.

${ }^{53}$ Há, ainda, outros menos unânimes ou menos notórios: DIDIER JR., Fredie. Curso de Direito Processual Civil: Introdução ao Direito Processual Civil, Parte Geral e Processo do Conhecimento, v. 1. 22 $2^{\mathrm{a}}$ ed. rev., atual. e ampl., Salvador: Juspodivm, 2020, p. 70-76.
} 
brasileiro com o apoio da doutrina. Como já dito, não faz mais sentido tratar como microssistemas apenas os conjuntos normativos que possuem seus núcleos inseridos em legislações extravagantes em relação aos Códigos.

Tendo tudo isso em vista, é imprescindível, à luz desse "novo" método hermenêutico, reconhecer a vigência de um Microssistema Recursal, regido pelas diversas disposições contidas, ao menos, no próprio CPC. Esse conjunto de normas, como se verá, possui todos os requisitos de existência de um microssistema no ponto de vista atual, pois tem seu núcleo nas disposições gerais sobre recursos e nas normas referentes à apelação, além de gerar um diálogo entre as diversas espécies recursais (institutos com finalidades análogas, de correção de decisões). Aliás, a existência de um intercâmbio entre as normas do Microssistema Recursal é demonstrada, principalmente, pelo fato de que doutrina e jurisprudência já aplicam os dispositivos de forma complementar, ainda que sem indicar o fenômeno do microssistema por trás dessa prática.

Além do já mencionado diálogo entre os recursos de revista repetitivos e os recursos especial e extraordinário repetitivos, cabe destacar o entendimento tradicional no Direito brasileiro de que o tipo recursal da apelação é considerado como o "recurso por excelência". ${ }^{54}$ Assim, dispositivos insertos no capítulo da apelação (arts. 1.009 ao 1.014 do CPC) estabelecem normas que se aplicam também a outros tipos recursais, mesmo com a existência de um capítulo de disposições gerais. Como exemplo disso, a normatização sobre o efeito devolutivo dos recursos, a partir do art. 1.013 do CPC, serve como regra geral aos outros tipos recursais. ${ }^{55}$ Sob o mesmo argumento, é aceita a tutela da evidência recursal, expressamente prevista apenas na apelação e nos embargos de declaração (arts. 1.012, § $4^{\circ}$, e $1.026, \S 1^{\circ}$, do CPC) a todas as espécies recursais. ${ }^{56}$

\footnotetext{
54 “(...) a apelação constitui o paradigma dos demais recursos ordinários (em sentido amplo). Ou seja, seu regime jurídico, em linhas gerais, serve de padrão subsidiário para as outras espécies de recursos de natureza ordinária. Por exemplo, as regras de extensão de profundidade do efeito devolutivo veiculadas na parte do Código dedicada à apelação, a rigor, constituem, com as devidas adaptações, as diretrizes também aplicáveis ao agravo de instrumento, ao agravo interno, ao recurso ordinário (em sentido estrito)." (WAMBIER, Luiz Rodrigues; TALAMINI, Eduardo. Curso avançado de processo civil volume 2: cognição jurisdicional (processo comum de conhecimento e tutela provisória). 19. ed. rev., atual. e ampl. São Paulo: Thomson Reuters Brasil, 2020, p. 536.) No mesmo sentido: MOREIRA, José Carlos Barbosa. Comentários ao Código de Processo Civil, Lei n $\mathrm{n}^{\circ}$ 5.869, de 11 de janeiro de 1973, vol. V: arts. 476 a 565. $17^{\text {a }}$ ed. rev. e atual. - Rio de Janeiro: Forense, 2013, p. 406 e 429.

${ }_{55}$ DIDIER JR., Fredie; CUNHA, Leonardo Carneiro da. Curso de direito processual civil: meios de impugnação às decisões judiciais e processo nos tribunais, v. 3. $17^{\mathrm{a}}$ ed. rev., atual. e ampl., Salvador: Juspodivm, 2020, p. 187-188.

${ }^{56}$ Enunciado n 423 do FPPC: "Cabe tutela de evidência recursal."
} 
Revista Eletrônica de Direito Processual - REDP.

Rio de Janeiro. Ano 16. Volume 23. Número 1. Janeiro a Abril de 2022

Periódico Quadrimestral da Pós-Graduação Stricto Sensu em Direito Processual da UERJ

Patrono: José Carlos Barbosa Moreira (in mem.). ISSN 1982-7636. pp. 458-481 www.redp.uerj.br

Paralelamente, cabe fazer referência à aplicação da "teoria da causa madura", prevista expressamente apenas para a apelação, no art. 1.013, $\S \S 3^{\circ}$ e $4^{\circ}$ do CPC, responsável por permitir que o segundo grau de jurisdição julgue o mérito do processo em sede de recurso. Sobre o tema, doutrina, ainda sob a vigência do CPC/1973, já apontava a possibilidade de aplicação da causa madura ao recurso ordinário constitucional. ${ }^{57}$ No mesmo sentido, a doutrina também sustenta a aplicação da teoria da causa madura ao agravo de instrumento, ${ }^{58}$ o que é igualmente corroborado pela jurisprudência. ${ }^{59}$

Percebe-se, então, que já se encontra pacificada, em certa medida, a ideia de que há sim uma intercomunicação entre dispositivos que regulam tipos recursais diferentes, funcionando a apelação como um ponto central com alto poder de influência. Ocorre, entretanto, que a característica sistematizadora do Microssistema Recursal não deve ficar restrita à apelação e às suas normas. A discussão passa, portanto, a ser de grau e de limites desse intercâmbio de técnicas processuais recursais.

Numa visão expansiva e consentânea com a ampliação hermenêutica sustentada, é possível, por exemplo, reconhecer a importância de se falar num microssistema recursal, em relação ao tema de aproveitamento de recursos, para que se possa extrair um "princípio da conversibilidade recursal", ${ }^{60}$ cujas normas, a rigor, estão previstas apenas nos embargos de

\footnotetext{
${ }^{57}$ Sob a vigência do CPC/1973: CÂMARA, Alexandre Freitas. Manual do mandado de segurança. São Paulo: Atlas, 2013, p. 244-252. Sob a vigência do CPC/2015: DIDIER JR., Fredie; CUNHA, Leonardo Carneiro da. Curso de direito processual civil: meios de impugnação às decisões judiciais e processo nos tribunais, v. 3. $17^{\mathrm{a}}$ ed. rev., atual. e ampl., Salvador: Juspodivm, 2020, p. 247-248. No mesmo sentido, o Enunciado n 357 do FPPC: “Aplicam-se ao recurso ordinário os arts. 1.013 e 1.014". Por outro lado, os tribunais, após certa divergência sobre essa questão, consolidaram entendimento no sentido de que não é possível a aplicação da causa madura ao recurso ordinário, entendimento que se revela absolutamente descabido: STJ - AgInt no RMS 48.321/MG, Rel. Ministro SÉRGIO KUKINA, PRIMEIRA TURMA, julgado em 30/03/2020, DJe 02/04/2020; STF - RMS 32199, Relator(a): TEORI ZAVASCKI, Segunda Turma, julgado em 05/05/2015, PROCESSO ELETRÔNICO DJe-151 DIVULG 31-07-2015 PUBLIC 03-08-2015.

${ }^{58}$ Sob a vigência do CPC/1973: DINAMARCO, Cândido Rangel. A reforma da reforma. $6^{a}$ ed., São Paulo: Malheiros, 2003, p. 162-163. ALVIM, Teresa Arruda. Os agravos no CPC brasileiro. $4^{\mathrm{a}}$ ed., São Paulo: RT, 2006, p. 349-350. RODRIGUES, Marcelo Abelha. Manual de Direito Processual Civil. $5^{\text {a }}$ ed., São Paulo: RT, 2010, p. 643-644. ALVIM, José Eduardo Carreira. Código de Processo Civil reformado. $7^{a}$ ed., Curitiba: Juruá, 2008, p. 351. Sob a vigência do CPC/2015: DIDIER JR., Fredie; CUNHA, Leonardo Carneiro da. Curso de direito processual civil: meios de impugnação às decisões judiciais e processo nos tribunais, v. 3. 17 a ed. rev., atual. e ampl., Salvador: Juspodivm, 2020, p. 307-308. No mesmo sentido, o Enunciado 705 do FPPC: "Aplicam-se os $\S \S 3^{\circ}$ e $4^{\circ}$ do art. 1.013 ao agravo de instrumento interposto contra decisão parcial de mérito." 59 STJ - REsp 1215368/ES, Rel. Ministro HERMAN BENJAMIN, CORTE ESPECIAL, julgado em 01/06/2016, DJe 19/09/2016.

${ }^{60}$ Referindo-se ao fenômeno da conversibilidade como princípio: CÂMARA, Alexandre Freitas. $O$ novo processo civil brasileiro. $2^{\mathrm{a}}$ ed., São Paulo: Atlas, 2017, p. 499. CABRAL, Antonio do Passo. Comentários ao art. 283, in: Comentários ao Novo Código de Processo Civil. CABRAL, Antonio do Passo; CRAMER, Ronaldo (Coord.). $2^{\mathrm{a}}$ ed. rev., atual. e ampl. Rio de Janeiro: Forense, 2016, p. 447.
} 
declaração e nos recursos extraordinários (arts. 1.024, § 3º 1.032 e 1.033 do CPC), mas que devem servir como parâmetro para seu uso indistinto, a qualquer espécie recursal, e como base para a mudança dos requisitos da fungibilidade recursal. ${ }^{61}$

Deve-se destacar, ainda, a aplicação do efeito suspensivo automático (ope legis) da apelação (art. 1.012 do CPC) ao agravo de instrumento interposto contra decisões de mérito (art. 1.015, I, do CPC), diante da identidade de situações jurídicas. Lutar contra essa ideia consiste em atribuir eficácias diferentes às decisões judiciais de conteúdo idêntico, simplesmente porque proferidas sob formas diferentes (decisão interlocutória ou sentença), tornando mais benéfico o julgamento parcial de mérito (por decisão interlocutória), pois essa decisão se tornará imediatamente exequível.

Além disso, em razão da interpretação conjunta com o art. 937, caput, seus incisos e seus $\S \S 1^{\circ}$ e $3^{\circ}$, do CPC, deve-se reconhecer o cabimento de sustentação oral em julgamento de agravo de instrumento interposto contra decisão com conteúdo de sentença, como acontece em uma decisão que julga parcial e antecipadamente o mérito do processo (art. 356, $\left.\S 5^{\circ}, \mathrm{CPC}\right) .{ }^{62}$

Outra questão que pode ser tecnicamente trabalhada é a possibilidade de aplicação do ius novorum (art. 1.014 do CPC) ao agravo de instrumento interposto pelo réu contra decisões liminares (proferidas, portanto, antes de sua oitiva). Nessa hipótese, deve-se permitir que o réu apresente fatos e provas novas no agravo, além de rediscutir a decisão com base no que já existe nos autos, medida que se revela mais eficaz para a tutela da duração razoável do processo e da eficiência; e não simplesmente impedir essa ampliação do efeito devolutivo, sob a alegação genérica de "supressão de instância", como se vê em diversos julgados. Afinal, como já dito, o duplo grau de jurisdição vem sendo crescentemente relativizado, mesmo em decisões definitivas (seja pelo art. 1.013, $\S \S 3^{\circ}$ e $4^{\circ}$, do CPC ou pelo prequestionamento ficto, expressamente consagrado pelo art. 1.025 do CPC), o que

\footnotetext{
${ }^{61}$ Sobre o tema: MARÇAL, Felipe Barreto. Levando a fungibilidade recursal a sério: pelo fim da "dúvida objetiva", do "erro grosseiro" e da "má-fé" como requisitos para a aplicação da fungibilidade e por sua integração com o CPC/15. Revista de Processo, v. 292, 2019. Também defendem a aplicação dos referidos dispositivos a qualquer espécie recursal: WAMBIER, Luiz Rodrigues; TALAMINI, Eduardo. Curso avançado de processo civil volume 2: cognição jurisdicional (processo comum de conhecimento e tutela provisória). 19. ed. rev., atual. e ampl. São Paulo: Thomson Reuters Brasil, 2020, p. 494.

${ }^{62}$ ARAÚJO, Luciano Vianna. Apelação cível no Código de Processo Civil 2015. Revista de Processo, v. 261, 2016, p. 281-312, versão eletrônica, p. 4.
} 
demonstra a aceitação dessa medida também para decisões provisórias (se o CPC e a doutrina admitem a exceção mais grave, não há razões para negar a exceção menos grave).

Por fim, já que o presente artigo não tem pretensão de exaurir as possibilidades, parte da doutrina sustenta intercâmbio normativo entre os embargos de divergência e os recursos repetitivos, a fim de empregar àqueles eficácia vinculante, já que ambos têm, como finalidade, compor divergências e evitar rediscussões dos mesmos temas. Assim, observados os requisitos estabelecidos para o microssistema de precedentes (que, em relação ao STJ e ao STF, são extraíveis principalmente dos recursos repetitivos), o acórdão que julga os embargos de divergência pode ter eficácia de precedente vinculante. ${ }^{63}$

\section{Conclusão}

O presente artigo pretendeu apontar a mudança de percepção dos microssistemas normativos, de modo que que sua concepção tradicional (dispositivos extraídos a partir de diferentes fontes normativas) se revela insuficiente para a realidade do ordenamento atual $\mathrm{e}$ para a finalidade de proporcionar integração normativa. Assim, a existência de um microssistema não fica limitada a essa ideia, mas também permite intercâmbio de normas situadas dentro do mesmo corpo legislativo, de modo que os microssistemas não precisam ter seus núcleos situados fora dos códigos, podendo até mesmo estarem totalmente inseridos neles, passando a constituir um verdadeiro bloco normativo. Em síntese, não havendo vedação expressa na legislação, deve-se admitir o diálogo normativo, mediante subsidiariedade e supletivismo.

Importante destacar uma outra vantagem hermenêutica dessa nova concepção, qual seja, a dispensa de que o legislador tenha antecipado essas interações normativas, o que permite ao intérprete atuar de forma mais "completa", dispondo de mais instrumentos processuais. Além disso, nada impede que um microssistema formado internamente (numa mesma lei) seja complementado por normas de leis extravagantes.

A partir dessas premissas, foram identificados os já consagrados microssistemas e alguns "novos", indicados pela doutrina. Além disso, o trabalho pretendeu demonstrar a

\footnotetext{
${ }^{63}$ Chegam à mesma conclusão, sem partir da premissa de um microssistema: FREIRE, Rodrigo Cunha Lima; LEMOS, Vinicius Silva. Os embargos de divergência como meio de formação de precedente vinculante. RePro, v. 299, 2020, p. 323-362.
} 
possibilidade (e a necessidade) de se reconhecer a existência de um microssistema recursal, que permite o intercâmbio de normas previstas para determinadas espécies recursais, de modo a garantir mais coerência e mais mecanismos de alcance dos objetivos pretendidos (princípios processuais) diante de cada um dos institutos analisados.

Espera-se, com isso, disseminar a ideia de um intercâmbio de técnicas processuais recursais, para que doutrina e jurisprudência possam perceber as possibilidades e os limites da existência de um microssistema recursal.

\section{REFERÊNCIAS:}

ALVIM, José Eduardo Carreira. Código de Processo Civil reformado. $7^{\mathrm{a}}$ ed., Curitiba: Juruá, 2008.

ALVIM, Teresa Arruda. Os agravos no CPC brasileiro. 4ª ed., São Paulo: RT, 2006.

ALVIM, Teresa Arruda; CONCEIÇÃO, Maria Lúcia Lins; RIBEIRO, Leonardo Ferres da Silva; MELLO, Rogério Licastro Torres de. Primeiros comentários ao Novo Código de Processo Civil. Artigo por artigo. São Paulo: RT, 2015.

ARAÚJO, Luciano Vianna. Apelação cível no Código de Processo Civil 2015. Revista de Processo, v. 261, 2016, p. 281-312, versão eletrônica.

AZEVEDO, Fernando Costa de. Uma introdução ao direito brasileiro do consumidor. Revista de Direito do Consumidor, v. 69, 2009, p. 32-86, versão eletrônica.

AZEVEDO, Marcelo Tadeu Freitas de. A natureza jurídica do incidente de resolução de demandas repetitivas. Revista de Processo, v. 278, 2018, p. 337-361, versão eletrônica.

BARROS, Marco Antonio Loschiavo Leme de. Processo, precedentes e as novas formas de justificação da Administração Pública Brasileira. Revista Digital de Direito Administrativo, v. 3, n. 1, 2016.

BASTOS, Fabrício Rocha. Do microssistema da tutela coletiva e sua interação com o CPC/15. Revista do Ministério Público do Rio de Janeiro, n. 68, 2018.

CABRAL, Antonio do Passo. A escolha da causa-piloto nos incidentes de resolução de processos repetitivos. Revista de Processo, n. 231, 2014. 
CABRAL, Antonio do Passo. Comentários ao art. 283, in: Comentários ao Novo Código de Processo Civil. CABRAL, Antonio do Passo; CRAMER, Ronaldo (Coord.). $2^{\mathrm{a}}$ ed. rev., atual. e ampl. Rio de Janeiro: Forense, 2016.

CABRAL, Antonio do Passo. Despolarização do processo e "zonas de interesse": sobre a migração entre polos da demanda, in: DIDIER JR., Fredie et al. (Coord.). Tutela jurisdicional coletiva. $2^{\text {a }}$ série. Salvador: Juspodivm, 2012.

CÂMARA, Alexandre Freitas. Juizados especiais cíveis estaduais, federais e da fazenda pública: uma abordagem crítica. $7^{\text {a }}$ ed., Rio de Janeiro: Lumen Juris, 2012.

CÂMARA, Alexandre Freitas. Levando os padrões decisórios a sério. São Paulo: Atlas, 2018.

CÂMARA, Alexandre Freitas. Manual do mandado de segurança. São Paulo: Atlas, 2013.

CÂMARA, Alexandre Freitas. O novo processo civil brasileiro. $2^{\mathrm{a}}$ ed., São Paulo: Atlas, 2017.

CUNHA, Leonardo Carneiro da. O regime processual das causas repetitivas. Revista de Processo, n. 179, 2010.

DIDIER JR., Fredie. Curso de direito processual civil: introdução ao direito processual civil, parte geral e processo do conhecimento, v. 1. 22 ed. rev., atual. e ampl., Salvador: Juspodivm, 2020.

DIDIER JR., Fredie. Intervenção de amicus curiae em processo apto à formação de precedente administrativo obrigatório. Civil Procedure Review, v. 11, n. 2, 2020.

DIDIER JR., Fredie; CABRAL, Antonio do Passo; CUNHA, Leonardo Carneiro. Por uma nova teoria dos procedimentos especiais. Salvador: Ed. JusPodivm, 2018.

DIDIER JR., Fredie; CUNHA, Leonardo Carneiro da. Curso de direito processual civil: meios de impugnação às decisões judiciais e processo nos tribunais, v. 3. 17 a ed. rev., atual. e ampl., Salvador: Juspodivm, 2020.

DIDIER JR., Fredie; CUNHA, Leonardo Carneiro da. Curso de direito processual civil: o processo civil nos tribunais, recursos, ações de competência originária de tribunal e querela nullitatis, incidentes de competência originária de tribunal. $13^{\mathrm{a}}$ ed. reform. Salvador: Juspodivm, 2016.

DIDIER JR., Fredie; OLIVEIRA, Rafael Alexandria de. Intimação de terceiros na execução judicial: uma análise do bloco normativo formado pelos arts. 799, 804 e 889 do 
Código de Processo Civil brasileiro. Revista Brasileira de Direito Processual, ano 28, n. $110,2020$.

DIDIER JR., Fredie; ZANETI JR., Hermes. Curso de direito processual civil: processo coletivo, v. 4. $10^{\mathrm{a}}$ ed., Salvador: Juspodivm, 2016.

DINAMARCO, Cândido Rangel. A reforma da reforma. $6^{\text {a }}$ ed., São Paulo: Malheiros, 2003. FONSECA, Rodrigo Garcia da. A arbitragem e a reforma processual da execução. Revista de Arbitragem e Mediação, v. 14, 2007, p. 30-47, versão eletrônica.

FREIRE, Rodrigo Cunha Lima; LEMOS, Vinicius Silva. Os embargos de divergência como meio de formação de precedente vinculante. RePro, v. 299, 2020.

KLAUSNER, Eduardo Antônio. A globalização e a proteção do consumidor brasileiro. Revista de Direito do Consumidor, v. 97, 2015, p. 67-84, versão eletrônica.

MARÇAL, Felipe Barreto. Levando a fungibilidade recursal a sério: pelo fim da "dúvida objetiva", do "erro grosseiro" e da "má-fé" como requisitos para a aplicação da fungibilidade e por sua integração com o CPC/15. Revista de Processo, v. 292, 2019.

MENDES, Aluisio Gonçalves de Castro; NETO, Odilon Romano. Análise da relação entre o novo incidente de resolução de demandas repetitivas e o microssistema dos juizados especiais. Revista de Processo, v. 245, 2015, p. 275-309, versão eletrônica.

MOREIRA, José Carlos Barbosa. A ação popular do direito brasileiro como instrumento de tutela dos chamados 'interesses difusos', in: Temas de direito processual - primeira série. São Paulo: Saraiva, 1988.

MOREIRA, José Carlos Barbosa. A legitimação para a defesa dos "interesses difusos" no direito brasileiro, in: Temas de direito processual - terceira série. São Paulo: Saraiva, 1984.

MOREIRA, José Carlos Barbosa. A proteção jurídica dos interesses coletivos, in: Temas de direito processual - terceira série. São Paulo: Saraiva, 1984.

MOREIRA, José Carlos Barbosa. Ações coletivas na Constituição Federal de 1988. Revista de Processo, n. 61, 1991.

MOREIRA, José Carlos Barbosa. Comentários ao Código de Processo Civil, Lei $\mathrm{n}^{\circ}$ 5.869, de 11 de janeiro de 1973, vol. V: arts. 476 a 565. 17 ed. rev. e atual. - Rio de Janeiro: Forense, 2013. 
MOREIRA, José Carlos Barbosa. Recorribilidade das decisões interlocutórias no processo do mandado de segurança, in: Temas de direito processual - sexta série. São Paulo: Saraiva, 1997.

PEREIRA, Vívian Lopes. A nova sistemática executiva do código de processo civil e os seus reflexos nos juizados especiais estaduais cíveis. Revista de Processo, v. 198, 2011, p. 297-317, versão eletrônica.

RAMOS, Paulo Roberto Barbosa. A filosofia do controle concentrado de constitucionalidade das leis na ordem jurídica brasileira pós-88. Revista de Direito Constitucional e Internacional, v. 37, 2001, p. 175-184, versão eletrônica.

RICKEN, Guilherme. O Código Austríaco. Portal Jurídico Investidura, Florianópolis/SC, 21 Jul. 2008. Disponível em: www.investidura.com.br/bibliotecajuridica/artigos/historia-do-direito/468-ocodaustr. Acesso em: 09/08/2020.

RODRIGUES, Marcelo Abelha. Manual de Direito Processual Civil. $5^{\text {a }}$ ed., São Paulo: RT, 2010.

ROQUE, Andre Vasconcelos. As ações coletivas após o Novo Código de Processo Civil: para onde vamos? In: DIDIER JR., Fredie; ZANETI JR., Hermes (coords.). Coleção repercussões do Novo CPC: processo coletivo, v.8. Salvador: Juspodivm, 2016.

SQUEFF, Tatiana de Almeida F. R. Cardoso. Bases constitucionais da defesa dos consumidores no Brasil: um resgate acerca da criação da legislação consumerista em prol da confirmação de sua posição privilegiada no ordenamento jurídico pátrio. Revista de Direito do Consumidor, v. 116, 2018, p. 129-149, versão eletrônica.

TEIXEIRA, Sálvio de Figueiredo. A proteção ao consumidor no sistema jurídico brasileiro. Revista de Direito do Consumidor, v. 60, 2006, p. 7-36, versão eletrônica.

TEMER, Sofia Orberg. Incidente de resolução de demandas repetitivas. Salvador: Juspodivm, 2016.

TEMER, Sofia Orberg. Participação no Processo Civil: repensando litisconsórcio, intervenção de terceiros e outras formas de atuação. Salvador: Juspodivm, 2020.

VIAL, Sophia Martini. O fenômeno da codificação e da recodificação do direito privado. Revista de Direito Privado, v. 64, 2015, p. 13-35, versão eletrônica. 
Revista Eletrônica de Direito Processual - REDP.

Rio de Janeiro. Ano 16. Volume 23. Número 1. Janeiro a Abril de 2022

Periódico Quadrimestral da Pós-Graduação Stricto Sensu em Direito Processual da UERJ

Patrono: José Carlos Barbosa Moreira (in mem.). ISSN 1982-7636. pp. 458-481

www.redp.uerj.br

VIEIRA, Marcelo de Mello. Considerações sobre microssistemas jurídicos: definição e importância à luz do direito civil-constitucional brasileiro. Juris Plenum, ano XVI, n. 91, 2020, p. 133-134.

WAMBIER, Luiz Rodrigues; TALAMINI, Eduardo. Curso avançado de processo civil volume 2: cognição jurisdicional (processo comum de conhecimento e tutela provisória). 19. ed. rev., atual. e ampl. São Paulo: Thomson Reuters Brasil, 2020. 